\title{
lonized calcium and 1,25-dihydroxyvitamin D concentration in serum of patients with sarcoidosis
}

\author{
K. Hamada*, S. Nagai*, T. Tsutsumi**, T. Izumi*
}

Ionized calcium and 1,25-dihydroxyvitamin D concentration in serum of patients with sarcoidosis. K. Hamada, S. Nagai, T. Tsutsumi, T. Izumi. (OERS Journals Ltd 1998.

ABSTRACT: The aim of this study was to evaluate alterations in calcium metabolism in sarcoidosis.

The serum concentrations of calcium ( $\mathrm{sCa}$ ), ionized calcium $\left(\mathrm{sCa}^{2+}\right), 1,25$-dihydroxyvitamin D $\left(\mathbf{s 1 , 2 5}(\mathrm{OH})_{2} \mathrm{D}_{3}\right)$ and parathyroid hormone (sPTH), serum angiotensin-converting enzyme activity (sACE) and urinary excretion of calcium (uCa) were studied in 36 Japanese patients with pulmonary sarcoidosis, aged 48.1 \pm 15.3 yrs (mean \pm SD), 15 males and 21 females. During the study the patients were on a daily diet with $500 \mathrm{mg}$ calcium and $1000 \mathrm{mg}$ phosphorus for a total of 6 days.

$\mathrm{SCa}^{2+}$ was above the normal range $\left(>1.26 \mathrm{mmol} \cdot \mathrm{L}^{-1}\right)$ in 10 patients $(27.8 \%), 12$ patients $(33.3 \%)$ were hypercalciuric, and 16 patients $(44.4 \%)$ showed alteration in calcium metabolism, with an increase in values of $\mathrm{sCa}, \mathrm{sCa}^{2+}$ or $\mathrm{uCa}$. There was a significant correlation between $\mathrm{sCa}^{2+}$ and $\left.\mathrm{s1,25(OH}\right)_{2} \mathrm{D}_{3}(\mathrm{p}<0.001)$, as well as between $\mathrm{sCa}^{2+}$ and $\mathrm{sACE}(\mathrm{p}<0.001) . \mathrm{s1,25}(\mathrm{OH})_{2} \mathrm{D}_{3}$ in patients with extrathoracic involvement (ETI) tended to be higher than in patients without ETI. sCa ${ }^{2+}$ was less than 1.23 mmol $\cdot \mathrm{L}^{-1}(\mathbf{p}<0.05)$ in the majority of patients without $\mathrm{ETI}$, and $\mathrm{SCa}^{2+}$ was less than $1.24 \mathrm{mmol} \cdot \mathrm{L}^{-1}$ in the majority of normocalciuric patients.

In conclusion, a disease-related alteration in calcium metabolism was seen in about $40 \%$ of patients with sarcoidosis, and 1,25 -dihydroxyvitamin D probably plays a crucial role in this abnormality. The serum concentration of ionized calcium was considered to be a useful index for the disease activity of sarcoidosis.

Eur Respir J 1998; 11: 1015-1020.
*Division of Pulmonary Medicine, Chest Disease Research Institute, Kyoto University, Kyoto, Japan. **Division of Pulmonary Medicine, National Utano Hospital, Kyoto, Japan.

Correspondence K. Hamada, Division of Pulmonary Medicine, Chest Disease Research Institute, 53 Kawaharacho, Shogoin, Sakyo-ku, Kyoto 606, Japan.

Fax: 81757514643

Keywords: Calcium metabolism, disease activity, ionized calcium, sarcoidosis, vita$\min \mathrm{D}$

Received: January 221997

Accepted after revision January 191998

Supported by a grant-in-aid for Medical Scientific Research (08670661) from the Ministry of Education, Japan and a grant from the Smoking Research Foundation in Japan.

The original data from this manuscript were presented at the Fourth Meeting of the World Association of Sarcoidosis and Other Granulomatous Diseases (WASOG) held in London, 1995
Serum ionized calcium, which constitutes $46-50 \%$ of serum calcium, is the only biologically active form of calcium. The serum concentration of ionized calcium $\left(\mathrm{sCa}^{2+}\right)$ is strictly regulated within a narrow range. For this reason, when evaluating calcium metabolism and interactions between calcium and vitamin $\mathrm{D}$ or between calcium and parathyroid hormone $(\mathrm{PTH}), \mathrm{sCa}^{2+}$ could be a more reliable index than the serum concentration of calcium $(\mathrm{sCa})$ or albumin-adjusted sCa (adjCa). 1,25-Dihydroxyvitamin D $\left(1,25(\mathrm{OH})_{2} \mathrm{D}_{3}\right)$, the most biologically active form of vitamin $\mathrm{D}$, is usually produced within renal tubules. Because the ultimate aim of this process is to keep $\mathrm{sCa}^{2+}$ stable, the production of $1,25(\mathrm{OH})_{2} \mathrm{D}_{3}$ in kidneys is strictly regulated by $\mathrm{sCa}^{2+}$, serum concentration of (s)PTH, and the serum concentration of phosphorus [1].

At granuloma sites, $1,25(\mathrm{OH})_{2} \mathrm{D}_{3}$ is produced by 25 -hydroxyvitamin D-1 $\alpha$-hydroxylase within activated alveolar macrophages and epithelioid cells, which play crucial roles in granuloma formation [2-4]. This extrarenal production of $1,25(\mathrm{OH})_{2} \mathrm{D}_{3}$, although not as tightly regulated as in the kidneys, occurs in a substrate-dependent manner $[2,5]$. A portion of extrarenally produced $1,25(\mathrm{OH})_{2}$ $\mathrm{D}_{3}$, taken into systemic blood circulation, probably causes an excess of calcium transport at the small intestine and, at the same time, an excess of bone resorption, which is thought to bring on an imbalance of calcium, hypercalcaemia or hypercalciuria, in patients with sarcoidosis [6-11].

Since HarRell and Fisher [12] suggested a positive correlation between vitamin $\mathrm{D}$ and hypercalcaemia in sarcoidosis for the first time in 1939 [12], a number of studies has been reported about the abnormal metabolism of calcium and vitamin D in patients with sarcoidosis. However, the significance of the correlation between $\mathrm{sCa}$ and $\mathrm{s} 1,25(\mathrm{OH})_{2} \mathrm{D}_{3}$ is thus far controversial.

In the current report, $\mathrm{sCa}^{2+}$ was the point of focus instead of $\mathrm{sCa}$. Whether or not $\mathrm{sCa}^{2+}$ reflects systemic extension of the disease and the disease activity was also studied by testing correlations with the activity of extrathoracic involvement (ETI) and hypercalciuria. Concerning an index for the disease activity of sarcoidosis, angiotensinconverting enzyme (sACE) has been one of the most reliable serum markers since LIEBERMAN et al. [13] reported its availability. However, it cannot be uniformly evaluated since the polymorphism of the gene was shown to affect sACE [14]. sACE still remains a useful index for disease activity, but alternative indices are needed that can reliably evaluate the activity of disease. In this respect an investigation was conducted into whether or not $\mathrm{sCa}^{2+}$ could reflect disease activity. 


\section{Methods}

\section{Materials}

Thirty six sarcoidosis patients, consisting of 15 males and 21 females aged $48.1 \pm 15.3$ yrs (mean \pm sD), were entered into the study (table 1 ). No entry criterion regarding disease duration was set in this study. The durations varied widely from 1-324 months, with three patients having been followed for $>5 \mathrm{yrs}$, and five patients in $>10 \mathrm{yrs}$. Six patients whose chest radiographs showed stage I or II sarcoidosis and presented elevated SACE and/or uveitis (the most frequent ETI among Japanese patients with sarcoidosis [15]), although not histologically proven, were clinically diagnosed with sarcoidosis. Histologically unproven patients whose chest radiograph did not show bilateral hilar lymphadenopathy (BHL) were excluded. Twenty eight patients had received no previous corticosteroid therapy, except for local use on ophthalmological or dermatological lesions, which was considered to have little systemic effect. Eight patients had previously had systemic corticosteroid therapy, but the treatment had been discontinued $>1 \mathrm{yr}$ before the study because of an improvement in symptoms. Patients who had received systemic corticos-

Table 1. - Profiles and radiographic data of 36 patients with sarcoidosis

\begin{tabular}{|c|c|}
\hline Data & Number \\
\hline$\overline{\text { Age yrs }(m e a n \pm S D)}$ & $48.1 \pm 15.3$ \\
\hline Males/females & $15 / 21$ \\
\hline Duration months (mean $\pm S D$ ) & $51 \pm 69$ \\
\hline \multicolumn{2}{|l|}{ Chest radiography stage* } \\
\hline 0 & 2 \\
\hline I & 12 \\
\hline II & 18 \\
\hline III & 4 \\
\hline \multicolumn{2}{|l|}{ Diagnosis } \\
\hline Transbronchial lung biopsy & 19 \\
\hline Skin biopsy & 5 \\
\hline Lymph node biopsy & 5 \\
\hline Liver biopsy & 1 \\
\hline Clinical $^{+}$ & 6 \\
\hline \multicolumn{2}{|l|}{ Symptoms } \\
\hline Asymptomatic & 12 \\
\hline Symptomatic & 24 \\
\hline Ocular & 16 \\
\hline Respiratory & 12 \\
\hline Febrile & 2 \\
\hline \multicolumn{2}{|l|}{ Extrathoracic lesion } \\
\hline Uveitis & 20 \\
\hline Skin & 10 \\
\hline Superficial lymph nodes & 5 \\
\hline Kidney & 1 \\
\hline Liver & 1 \\
\hline History of nephrolithiasis & 3 \\
\hline \multicolumn{2}{|l|}{ Treatment } \\
\hline Untreated & 28 \\
\hline Previous corticosteroid therapy\# & 8 \\
\hline Current therapy & 0 \\
\hline
\end{tabular}

*: defined as: 0: normal; I: bilateral hilar lymphadenopathy (BHL); II: BHL with pulmonary infiltrates; III: pulmonary infiltrates without BHL. +: diagnosis is based on clinical data, although the biopsy was negative for sarcoid granuloma. In this setting patients whose chest radiograph showed stage 0 and III were excluded. \#: patients who were treated with corticosteroid within $1 \mathrm{yr}$ before the study were excluded. teroid therapy within $1 \mathrm{yr}$ before the study were excluded. All patients had normal renal function except for two patients who had histories of nephrolithiasis and slightly reduced creatinine clearance. Patients were excluded if they had been diagnosed with hyperparathyroidism or hypoparathyroidism and primary bone diseases before the study. No primary or secondary endocinological disorders, except those due to sarcoidosis, were detected at the time of the study.

\section{Methods}

All patients were prevented from being exposed to sunlight and received $500 \mathrm{mg}$ of calcium and $1000 \mathrm{mg}$ of phosphorus orally for 6 days before their blood and urine were examined. Urinary excretion of calcium was measured after the urine had been stored for $24 \mathrm{~h}$. Hypercalciuria was diagnosed when the urinary excretion of calcium exceeded $0.3 \mathrm{~g} \cdot$ day $^{-1}$ in males, and $0.25 \mathrm{~g} \cdot \mathrm{day}^{-1}$ in females. $\mathrm{sCa}^{2+}$ was measured with an ion-sensitive electrode procedure, and its coefficients of variation (CV) were: interassay CV: $0.9 \%$ (low level), 0.4\% (middle level) and $0.2 \%$ (high level); and intra-assay CV: $0.8 \%$ (low level), $1.1 \%$ (middle level) and $0.8 \%$ (high level). The adjusted concentration of serum calcium (adjCa) was calculated as ( $\mathrm{sCa}$ $\mathrm{mg} \cdot \mathrm{dL}^{-1}+(4.0$ - serum concentration of albumin $\left.\mathrm{g} \cdot \mathrm{dL}-1)\right) /$ $4.01 \mathrm{mmol} \cdot \mathrm{L}^{-1}$.

$\mathrm{s} 1,25(\mathrm{OH})_{2} \mathrm{D}_{3}$ was measured by radioreceptor assay (RRA) using $1,25(\mathrm{OH})_{2} \mathrm{D}_{3}$ receptors derived from bovine mammary glands. The interassay $\mathrm{CV}$ were $8.78 \%$ (low level), $7.46 \%$ (middle level) and $11.6 \%$ (high level); and the intra-assay CV were $7.97 \%$ (low-level), $8.68 \%$ (middle level) and $16.7 \%$ (high level).

sPTH was measured by radioimmunoassay (RIA) using two antibodies specific to the fragment (from the 44th to 68th amino acids) of PTH. The interassay CV of this method were $10.06 \%$ (low level), $4.12 \%$ (middle level) and $5.87 \%$ (high level); and the intra-assay CV were $9.05 \%$ (low level), 6.21\% (middle level) and 3.62\% (high level).

sACE was measured with an optical density spectrometer at the wavelengths of $505 \mathrm{~nm}$ and $800 \mathrm{~nm}$. The interassay $\mathrm{CV}$ were $4.15 \%$ (low level), $3.67 \%$ (middle level) and $2.80 \%$ (high level); and the intra-assay CV were $2.37 \%$ (low level), $1.79 \%$ (middle level) and $1.81 \%$ (high level).

Classification of chest radiographs was performed in accordance with the following classic criteria: stage 0 : normal; stage I: BHL; stage II: BHL with pulmonary infiltrates; and stage III: pulmonary infiltrates without BHL. Every patient, even if asymptomatic, underwent ophthalmological examinations in order to detect uveitis and glaucoma. A dermatological biopsy was performed if the patient had a skin lesion suspected of being a sarcoid lesion. A thallium scan of the myocardium was performed when abnormal cardiac function was suspected on electrocardiography, or when an elevated cardiothoracic ratio was detected on chest radiography.

Informed consent about the restricted diet and all examinations to be carried out was obtained from each patient. This study was approved by the Ethical Committee of the Chest Disease Research Institute, Kyoto University. 


\section{Statistical analysis}

Student's t-test and the Mann-Whitney U-test were used to compare two groups, and Pearson's method was selected for evaluating correlations. Using the receiver-operating characteristic (ROC) curve, discriminant analyses were performed to determine appropriate cut-off values [16].

\section{Results}

\section{Incidence of hypercalcaemia and hypercalciuria}

$\mathrm{sCa}$ and adjCa were above the normal range in three $(9.8 \%)$ and two $(5.6 \%)$ patients, respectively. In the same group $\mathrm{sCa}^{2+}$ were above the normal range in 10 patients $(27.8 \%)$, of whom six $(60.0 \%)$ were hypercalciuric. Twelve patients $(33.3 \%)$ were hypercalciuric, of whom six $(50.0 \%)$ showed increased $\mathrm{sCa}^{2+}$. A history of nephrolithiasis had been detected in three patients. Values above the normal range for $\mathrm{sCa}$, adjCa, $\mathrm{sCa}^{2+}$ or urine concentrations of $(\mathrm{u}) \mathrm{Ca}$, were detected in 16 patients $(44.4 \%)$. Elevated levels of $\mathrm{s} 1,25(\mathrm{OH})_{2} \mathrm{D}_{3}$ were shown in 5 patients (11.6\%), four of whom were hypercalcaemic and/or hypercalciuric. One hypercalcaemic patient showed a decreased serum concentration of inorganic phosphorus ( $\mathrm{sPi}$ ) (see table 2).

Tentative cut-off value for $\mathrm{SCa}^{2+}$ to evaluate the presence of ETI

$\mathrm{SCa}^{2+}$ of patients with ETI and without ETI were 1.26 $0.10 \mathrm{mmol} \cdot \mathrm{L}^{-1}$ and $1.21 \pm 0.02 \mathrm{mmol} \cdot \mathrm{L}^{-1}$, respectively (fig. 1). According to the ROC curve (fig. 2), a value of 1.23 $\mathrm{mmol} \cdot \mathrm{L}^{-1}$ of $\mathrm{sCa}^{2+}$ was determined as a cut-off value to evaluate the presence or the absence of ETI. In this report the sensitivity of this cut-off value was $50 \%$, whereas the specificity was $100 \%$. All 8 patients without ETI showed $<1.23 \mathrm{mmol} \cdot \mathrm{L}^{-1}$ of $\mathrm{sCa}^{2+}$, whereas all patients who showed levels $>1.23 \mathrm{mmol} \cdot \mathrm{L}^{-1}$ of $\mathrm{sCa}^{2+}$ had ETI $(\mathrm{p}<0.05)$ (table $3)$.

Table 2. - Values related to calcium homeostasis in 36 patients with sarcoidosis*

\begin{tabular}{lcc}
\hline & Mean $\pm \mathrm{SD}$ & Normal ranges \\
\hline $\mathrm{sCa} \mathrm{mmol} \cdot \mathrm{L}^{-1}$ & $2.36 \pm 0.16$ & $2.09-2.54$ \\
adjCa mmol $\cdot \mathrm{L}^{-1}$ & $2.19 \pm 0.19$ & $2.09-2.54$ \\
$\mathrm{sCa}+\mathrm{mmol} \cdot \mathrm{L}^{-1}$ & $1.25 \pm 0.09$ & $1.10-1.26$ \\
$\mathrm{uCa} \mathrm{g} \cdot \mathrm{day}^{-1}$ & & \\
$\quad \mathrm{Male}$ & $0.243 \pm 0.142$ & $<0.3$ \\
$\quad \mathrm{Female}$ & $0.206 \pm 0.095$ & $<0.25$ \\
$\mathrm{sPi} \mathrm{mg} \cdot \mathrm{dL}^{-1}$ & $3.4 \pm 0.4$ & $2.5-4.5$ \\
$\mathrm{~s} 1,25(\mathrm{OH})_{2} \mathrm{D}_{3} \mathrm{pg} \cdot \mathrm{mL}^{-1}$ & $46.4 \pm 18.7$ & $20-60$ \\
$\mathrm{sPTH} \mathrm{pg} \cdot \mathrm{mL}^{-1}$ & $281.7 \pm 99.0$ & $260-560$ \\
\hline
\end{tabular}

sCa: serum concentration of calcium; adjCa: albumin-adjusted $\mathrm{sCa} ; \mathrm{sCa}^{2+}$ : serum concentration of ionized calcium; $\mathrm{uCa}$ : daily urinary excretion of calcium; sPi: serum concentration of inorganic phosphorus; $\mathrm{s} 1,25(\mathrm{OH})_{2} \mathrm{D}_{3}$ : serum concentration of 1,25 dihydroxyvitamin D; sPTH: serum concentration of parathyroid hormone. *: the serum angiotensin-converting enzyme activity (sACE) of these patients was $23.0 \pm 8.9 \mathrm{IU} \cdot \mathrm{L}^{-1}$ (normal range 8.321.4).
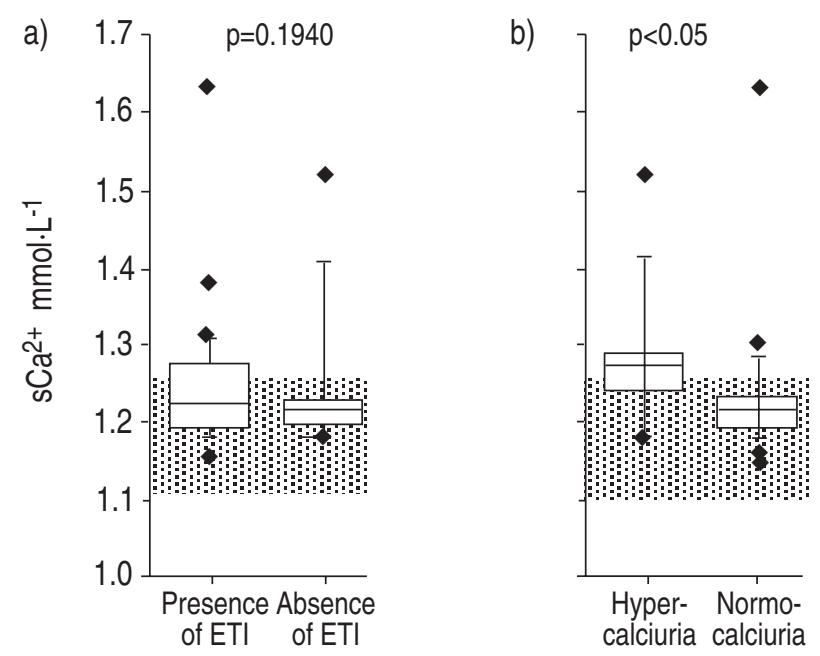

Fig. 1. - Box-whisker plots comparing serum concentration of ionized calcium $\left(\mathrm{sCa}^{2+}\right)$ between two groups of patients with sarcoidosis: a) presence $v s$ absence of extrathoracic involvement (ETI); and b) hypercalciuria vs normocalciuria. Upper and lower bars indicate the 90th and 10 th percentile, respectively, upper and lower margins of boxes indicate the 75 th and 25 th percentile, respectively, and the middle lines of the boxes indicate medians. Normal ranges are represented by the shaded zones. Significant difference between hypercalciuria and normocalciuria $(\mathrm{p}<0.05)$

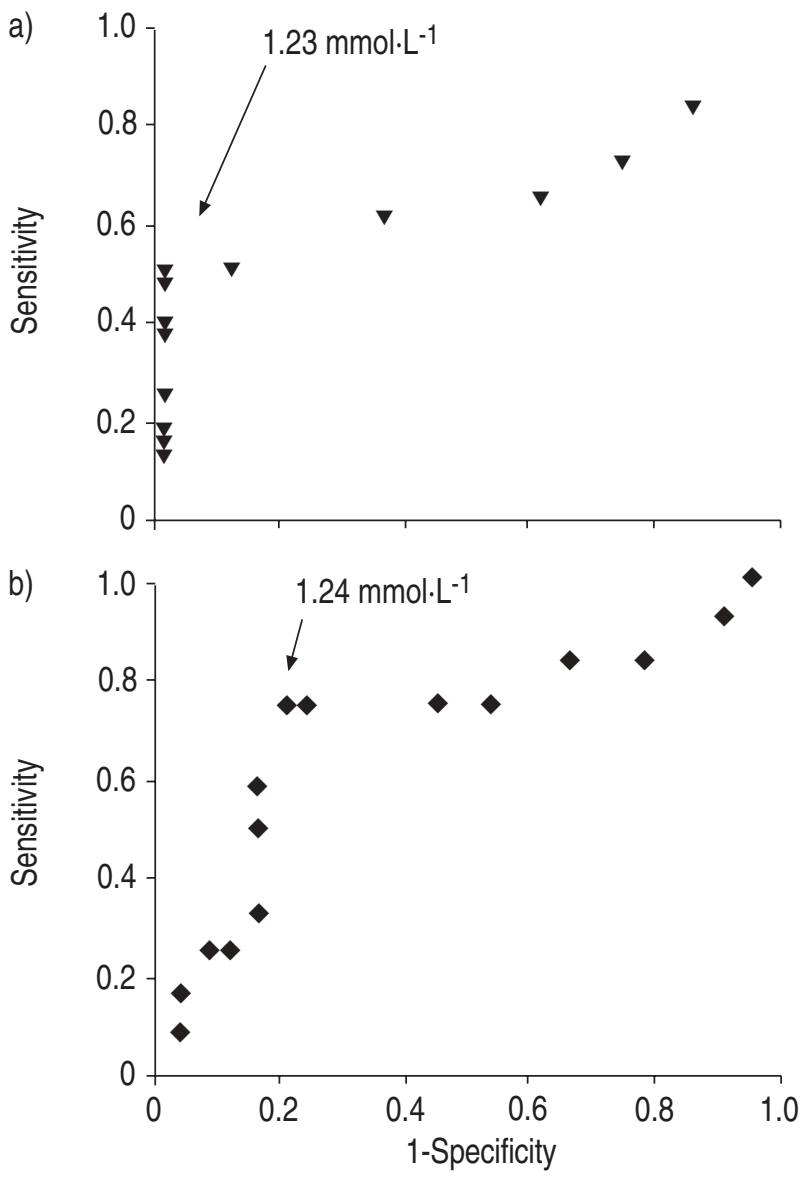

Fig. 2. - Receiver-operating characteristic (ROC) curves representing discriminant analyses with serum concentration of ionized calcium $\left(\mathrm{sCa}^{2+}\right)$ : a) extrathoracic involvement; and b) hypercalciuria. The arrows inside the figures indicate cut-off values for sCa ${ }^{2+}$ : a) $1.23 \mathrm{mmol} \cdot \mathrm{L}^{-1}$ and b) $1.24 \mathrm{mmol} \cdot \mathrm{L}^{-1}$. 
Table 3. - Cut-off value of $\mathrm{sCa} a^{2+}$ to evaluate the presence of $E T I$ in patients with sarcoidosis

\begin{tabular}{|c|c|c|c|}
\hline & & & \\
\hline ETI & $\begin{array}{c}>1.23 \mathrm{mmol} \cdot \mathrm{L}^{-1} \\
\mathrm{n}=14\end{array}$ & $\underset{\mathrm{n}=22}{\partial 1.23 \mathrm{mmol} \cdot \mathrm{L}^{-1}}$ & \\
\hline Present & 14 & 14 & \\
\hline Absent & 0 & 8 & $\mathrm{p}<0.05$ \\
\hline
\end{tabular}

The cut-off value of $1.23 \mathrm{mmol} \cdot \mathrm{L}^{-1}$ was determined with discriminant analysis using a receiver-operating characteristic curve. $\mathrm{sCa}^{2+}$ : serum concentration of ionized calcium; ETI: extrathoracic involvement.

Table 4. - Cut-off value of $\mathrm{sCa}^{2+}$ to evaluate hypercalciuria in patients with sarcoidosis

\begin{tabular}{|c|c|c|c|}
\hline & & & \\
\hline & $\begin{array}{c}>1.24 \mathrm{mmol} \cdot \mathrm{L}^{-1} \\
\mathrm{n}=13\end{array}$ & $\begin{array}{c}\text { ð } 1.24 \mathrm{mmol} \cdot \mathrm{L}^{-1} \\
\mathrm{n}=23\end{array}$ & \\
\hline Hypercalciuric & 9 & 3 & \\
\hline Normocalciuric & 4 & 20 & $\mathrm{p}<0.01$ \\
\hline
\end{tabular}

The cut-off value of $1.24 \mathrm{mmol} \cdot \mathrm{L}^{-1}$ was determined with discriminant analysis using a receiver-operating characteristic curve. $\mathrm{sCa}^{2+}$ : serum concentration of ionized calcium.

sACE and $s 1,25(\mathrm{OH})_{2} \mathrm{D}_{3}$ in patients with ETI and those without ETI

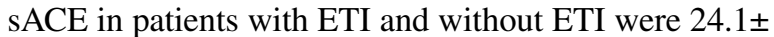
$9.3 \mathrm{IU} \cdot \mathrm{L}^{-1}$ and $19.1 \pm 5.8 \mathrm{IU} \cdot \mathrm{L}^{-1}$, respectively $(\mathrm{p}=0.1594)$, and $\mathrm{s} 1,25(\mathrm{OH})_{2} \mathrm{D}_{3}$ were $49.3 \pm 9.5 \mathrm{pg} \cdot \mathrm{mL}^{-1}$ and $36.4 \pm 12.2$ $\mathrm{pg} \cdot \mathrm{mL}^{-1}$, respectively $(\mathrm{p}=0.0707)$.

\section{$s \mathrm{Ca}^{2+}$ as an index of hypercalciuria}

Hypercalciuria was observed in six out of 10 patients who showed elevated $\mathrm{sCa}^{2+}$. Six out of 12 hypercalciuric patients were normocalcaemic. The mean for $\mathrm{sCa}^{2+}$ was $1.28 \pm 0.09 \mathrm{mmol} \cdot \mathrm{L}^{-1}$, (normal range $1.10-1.26 \mathrm{mmol} \cdot \mathrm{L}^{-1}$ ) in hypercalciuric patients, which was significantly higher than the value of $1.23 \pm 0.09 \mathrm{mmol} \cdot \mathrm{L}^{-1}(\mathrm{p}<0.05)$ found in normocalciuric patients (fig. 1). With a discriminant analysis to evaluate hypercalciuria, using a ROC curve, 1.24 $\mathrm{mmol} \cdot \mathrm{L}^{-1}$ of $\mathrm{sCa}^{2+}$ was determined as a cut-off value (fig. 2 ). The sensitivity and specificity of this cut-off value were $75.0 \%$ and $83.3 \%$, respectively, in this study. Nine out of $13(69.2 \%)$ patients whose $\mathrm{sCa}^{2+}$ were above this cut-off value were hypercalciuric, while 20 out of 23 $(87.0 \%)$ patients whose $\mathrm{sCa}^{2+}$ were less than this value were normocalciuric $(\mathrm{p}<0.01)$ (table 4$)$.

\section{Relations between $s \mathrm{Ca}^{2+}, \mathrm{s} 1,25(\mathrm{OH})_{2} \mathrm{D}_{3}$ and $s \mathrm{PTH}$}

Ten patients showed sPTH below the normal range (230-560 pg. $\left.\mathrm{mL}^{-1}\right): 171.1 \pm 31.4 \mathrm{pg} \cdot \mathrm{mL}^{-1}($ mean $\pm \mathrm{sD})$, while 23 patients were within the normal range: $329.8 \pm 76.7$ $\mathrm{pg} \cdot \mathrm{mL}^{-1}$ (sPTH was not measured in three patients). Among the 10 patients with low SPTH, four showed elevated $\mathrm{sCa}^{2+}$, five were hypercalciuric and none showed elevated $\mathrm{s} 1,25(\mathrm{OH})_{2} \mathrm{D}_{3}$. Four of these 10 patients showed no extranormal values of $\mathrm{sCa}^{2+}$, uCa or $\mathrm{s} 1,25(\mathrm{OH})_{2} \mathrm{D}_{3}$. Patients with low sPTH showed significantly higher values of $\mathrm{sCa}^{2+}$ than those with normal sPTH, $1.25 \pm 0.04 \mathrm{mmol} \cdot \mathrm{L}^{-1}$ and $1.24 \pm 0.12 \mathrm{mmol} \cdot \mathrm{L}^{-1}$, respectively $(\mathrm{p}<0.05)$. No significant difference in $s 1,25(\mathrm{OH})_{2} \mathrm{D}_{3}$ was observed between the two groups.

Table 5. - Correlations among parameters of calcium metabolism in 36 patients with sarcoidosis

\begin{tabular}{|c|c|c|}
\hline & $\mathrm{r}$ & $\mathrm{p}$-value \\
\hline $\mathrm{sCa} v s \mathrm{~s} 1,25(\mathrm{OH})_{2} \mathrm{D}_{3}$ & 0.541 & $<0.001$ \\
\hline $\operatorname{adjCa} v s \mathrm{~s} 1,25(\mathrm{OH})_{2} \mathrm{D}_{3}$ & 0.552 & $<0.001$ \\
\hline $\mathrm{sCa}^{2+} v s \mathrm{~s} 1,25(\mathrm{OH})_{2} \mathrm{D}_{3}$ & 0.554 & $<0.001$ \\
\hline $\mathrm{uCa} v s \mathrm{~s} 1,25(\mathrm{OH})_{2} \mathrm{D}_{3}$ & 0.321 & NS \\
\hline $\mathrm{sCa} v s \mathrm{sACE}$ & 0.288 & NS \\
\hline $\operatorname{adjCa} v s$ sACE & 0.423 & $<0.01$ \\
\hline $\mathrm{sCa}^{2+} v s \mathrm{sACE}$ & 0.517 & $<0.001$ \\
\hline $\mathrm{uCa} v s \mathrm{sACE}$ & 0.146 & NS \\
\hline $\mathrm{sCa}^{2+} v s \mathrm{sPTH}$ & 0.114 & NS \\
\hline $\mathrm{sCa}^{2+} v s \mathrm{sPi}$ & -0.294 & NS \\
\hline $\mathrm{sCa}^{2+} v s \mathrm{uCa}$ & 0.300 & NS \\
\hline sPi $v s \mathrm{sPTH}$ & 0.123 & NS \\
\hline sPi $v s \mathrm{~s} 1,25(\mathrm{OH})_{2} \mathrm{D}_{3}$ & -0.011 & NS \\
\hline $\mathrm{sPTH} v s \mathrm{~s} 1,25(\mathrm{OH})_{2} \mathrm{D}_{3}$ & 0.120 & No \\
\hline
\end{tabular}

Ns: nonsignificant. For other abbreviations see legend to table 2.
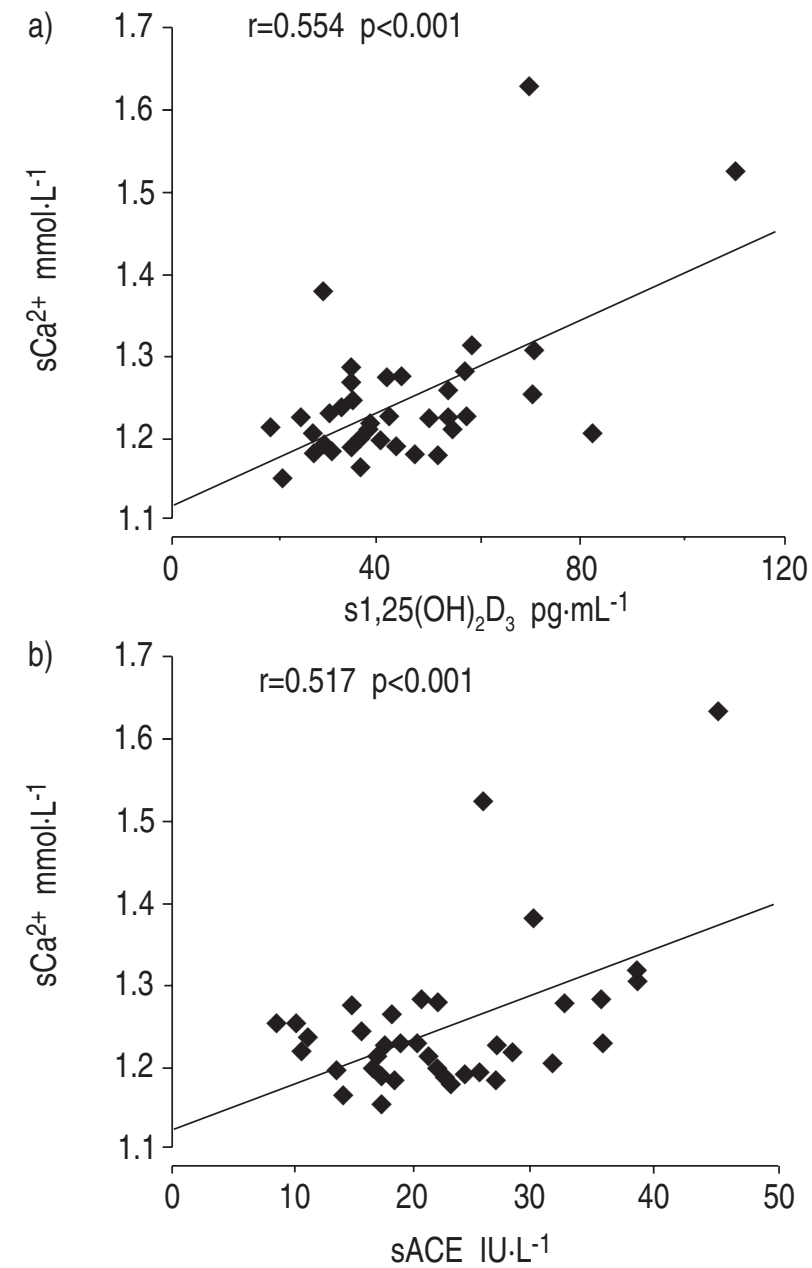

Fig. 3. - Correlation between a) serum concentration of 1,25-dihydroxyvitamin $\mathrm{D}\left(\mathrm{s} 1,25(\mathrm{OH})_{2} \mathrm{D}_{3}\right)$ and serum concentration of ionized calcium $\left(\mathrm{sCa}^{2+}\right)(\mathrm{r}=0.554, \mathrm{p}<0.001)$ and $\left.\mathrm{b}\right)$ serum activity of angio-tensinconverting enzyme (sACE) and $\mathrm{sCa}^{2+}(\mathrm{r}=0.517, \mathrm{p}<0.001)$ in pati-ents with sarcoidosis. Normal ranges are: $\mathrm{sCa}^{2+}$ : $1.10-1.26 \mathrm{mmol} \cdot \mathrm{L}^{-1}$; $\mathrm{s} 1,25(\mathrm{OH})_{2} \mathrm{D}_{3}: 20-60 \mathrm{pg} \cdot \mathrm{mL}^{-1}$; sACE: $8.3-21.4 \mathrm{IU} \cdot \mathrm{mL}^{-1}$. 


\section{Correlations among indices}

$\mathrm{s} 1,25(\mathrm{OH})_{2} \mathrm{D}_{3}$ showed significant correlations with $\mathrm{sCa}$, adjCa and $\mathrm{sCa}^{2+}(\mathrm{r}=0.541,0.552,0.554, \mathrm{p}<0.001$, respectively) (table 5). sACE also showed significant correlations with adjCa and $\mathrm{sCa}^{2+}(\mathrm{r}=0.423, \mathrm{p}<0.01$ and $\mathrm{r}=0.517$, $\mathrm{p}<0.001$, respectively). sPi showed no significant correlation with any index measured in this study. No significant correlation was detected between sACE and s1,25(OH) $\mathrm{D}_{3}$ (fig. 3).

\section{Discussion}

In the current study imbalance of calcium homeostasis in patients with sarcoidosis was re-evaluated, using $\mathrm{sCa}^{2+}$ as an index. sCa and adjCa were elevated in only a few patients, whereas $27.8 \%$ of patients showed elevated $\mathrm{sCa}^{2+}$. Using $\mathrm{sCa}^{2+}$ as an index, hypercalcaemia was observed rather commonly among Japanese patients with pulmonary sarcoidosis, even though it has been reported to be uncommon. An imbalance in calcium homeostasis was observed in $44.4 \%$ of the patients, which was almost the highest frequency ever reported $[2,9]$.

Hypercalciuria is an important clinical manifestation and a reflection of the disease activity of sarcoidosis. However thus far, its pathogenesis has not been precisely understood. The relation between serum concentration and daily urinary excretion of calcium did not seem to be simple and linear. In the current study, no significant correlation was observed between $\mathrm{uCa}$ and any other index, such as $\mathrm{sCa}$, adjCa or $\mathrm{sCa}^{2+}$. A discrepancy was observed between hypercalcaemia and hypercalciuria. Hypercalcaemic patients were not always hypercalciuric, and vice versa. That is, six $(54.5 \%)$ out of 12 hypercalciuric patients were normocalcaemic, and five $(50.0 \%)$ out of 10 hypercalcaemic patients (including those with elevated $\mathrm{sCa}^{2+}$ ) were normocalciuric. Hypercalciuria with an elevated $\mathrm{sCa}$ suggests elevated calcium absorption from the intestine or resorption from the bone, whereas, hypercalciuria with a low $\mathrm{sCa}$ suggests calcium leakage from the kidneys [17]. In patients with sarcoidosis more than half of the hypercalciuric patients were normocalcaemic. There-fore, other factors such as alterations in the threshold of calcium excretion in kidneys may be taken into consideration, in addition to hypercalcaemia, to explain the pathogenesis of hypercalciuria in patients with sarcoidosis.

Whether or not $\mathrm{sCa}^{2+}$ could be useful as an index for disease activity for sarcoidosis was also investigated. $\mathrm{SCa}^{2+}$ showed a significant correlation with $\mathrm{SACE}$, which has already been established as an index for disease activity of sarcoidosis $[13,18]$, although a direct pathophysiological relation between $\mathrm{SCa}^{2+}$ and $\mathrm{sACE}$ has not yet been described. Concomitant production of $1,25(\mathrm{OH})_{2} \mathrm{D}_{3}$ and ACE by activated macrophages and epithelioid cells in granulomas may play a crucial role in the correlation between $\mathrm{sCa}^{2+}$ and $\mathrm{sACE}$, although no significant correlation was observed between $\mathrm{sACE}$ and $\mathrm{s} 1,25(\mathrm{OH})_{2} \mathrm{D}_{3}$ in the current study.

Box-whisker plots of $\mathrm{sCa}^{2+}$ showed no significant difference between patients who had ETI and those who did not (fig. 1). In order to examine the relation to the presence of ETI, a discriminant analysis was performed, using a ROC curve (fig. 2). A low value of $\mathrm{sCa}^{2+}$ did not necessarily mean the absence of ETI, but a high value of $\mathrm{sCa}^{2+}$ $\left(>1.23 \mathrm{mmol} \cdot \mathrm{L}^{-1}\right.$ in this study) strongly suggested the pres- ence of ETI $(p<0.05)$. Although the presence of ETI does not necessarily reflect either the disease activity itself or the total quantity of granulomas, it suggests systemic extension of sarcoid lesions.

Hypercalciuric patients showed higher $\mathrm{sCa}^{2+}$ than normocalciuric patients $(\mathrm{p}<0.05)$ (fig. 1). Another discriminant analysis was performed using the ROC curve, from which a cut-off value of $1.24 \mathrm{mmol} \cdot \mathrm{L}^{-1}$ for $\mathrm{sCa}^{2+}$ was determined to evaluate hypercalciuria or normocalciuria (fig. 2 ). This discriminant analysis for evaluating hypercalciuria based on $\mathrm{sCa}^{2+}$ could be of clinical use, because $\mathrm{uCa}$ can be roughly evaluated without the $24 \mathrm{~h}$ storage of urine.

Two cut-off values for $\mathrm{sCa}^{2+}$ were tentatively determined in the current study, i.e. $1.23 \mathrm{mmol} \cdot \mathrm{L}^{-1}$, and $1.24 \mathrm{mmol}$. $\mathrm{L}^{-1}$, for evaluating the presence of ETI and hypercalciuria, respectively. $\mathrm{sCa}$ and adjCa did not contribute to such discriminant analyses. These similar values seem to show a border range for evaluating the disease activity of sarcoidosis, although the number of cases studied was small. Further investigation should be performed with a sufficient number of cases in order to judge the feasibility of using $\mathrm{sCa}^{2+}$ to evaluate the disease activity of sarcoidosis.

$\mathrm{s} 1,25(\mathrm{OH})_{2} \mathrm{D}_{3}$ showed higher values in patients with ETI, although this was not statistically significant. 1,25 $(\mathrm{OH})_{2} \mathrm{D}_{3}$ is reported not only to participate in calcium metabolism, but also to activate monocytes-macrophages and to promote their maturation [19-23], and, furthermore, to regulate and suppress T-cell activity [24-28]. It is possible that $1,25(\mathrm{OH})_{2} \mathrm{D}_{3}$ plays an important role in granuloma formation $[3,4,29,30]$. In addition, recent studies revealed that the vitamin $\mathrm{D}$ binding protein itself is a precursor of the macrophage activating factor [31].

Although the migration and accumulation of activated T-cells are considered to precede granuloma formation, the granuloma consists of nothing more than maturing macrophages and epithelioid cells [32-35]. Since epithelioid cells might be one of the mature forms of mononuclear phagocytes, it would be worthwhile to investigate the precise pathophysiological role of vitamin D metabolism in sarcoidosis.

In normal subjects, the production of $1,25(\mathrm{OH})_{2} \mathrm{D}_{3}$ in the kidneys is strictly regulated by $\mathrm{sCa}^{2+}, \mathrm{sPTH}$ and $\mathrm{sPi}$ [1]. A decrease in $\mathrm{sPi}$ or $\mathrm{sCa}^{2+}$ stimulates 25 -hydroxyvitamin D-1 $\alpha$-hydroxylase in the kidneys, either directly or via mediation by PTH. An increase in $\mathrm{s} 1,25(\mathrm{OH})_{2} \mathrm{D}_{3}$ suppresses the endocrine release of PTH from the parathyroid glands. Therefore, inverse correlations are expected between $\mathrm{s} 1,25(\mathrm{OH})_{2} \mathrm{D}_{3}$ and each of such factors as $\mathrm{sPi}, \mathrm{sCa}^{2+}$ and SPTH. As shown in table 5, however, any form of calcium concentration in the serum showed a significantly positive correlation with $\mathrm{s} 1,25(\mathrm{OH})_{2} \mathrm{D}_{3}$, whereas $\mathrm{sPi}$ and sPTH did not show any significant correlation with s1,25 $(\mathrm{OH})_{2} \mathrm{D}_{3}$ in patients with sarcoidosis. However, as $\mathrm{sCa}^{2+}$ was higher in patients with low SPTH than in those with normal sPTH, an inverse correlation between $\mathrm{sCa}^{2+}$ and sPTH seemed to be probable. No clear evidence regarding the reciprocal regulation between $\mathrm{sPTH}$ and $\mathrm{s} 1,25(\mathrm{OH})_{2}$ $\mathrm{D}_{3}$ was seen in the current study.

The results support the former hypothesis that diseaserelated alterations to calcium metabolism in patients with sarcoidosis are induced by extrarenal $1,25(\mathrm{OH})_{2} \mathrm{D}_{3}$ which is produced within sarcoid granulomas, and that the production of $1,25(\mathrm{OH})_{2} \mathrm{D}_{3}$ is regulated not in a normal manner but in a substrate-dependent fashion. 
In conclusion, imbalances of calcium homeostasis were clearly detected using $\mathrm{sCa}^{2+}$ as an index in Japanese patients with sarcoidosis. Elevated $\mathrm{sCa}^{2+}$, suggesting the presence of ETI and hypercalciuria, was considered to reflect the disease activity of sarcoidosis.

Acknowledgements: The authors thank F. Tanioka, Y. Imai and K. Kobayashi for their help in collecting clinical data, M. Shigematsu for the management of the outpatient clinic, their colleagues for co-operation and A. Johnson for checking linguistic problems.

\section{References}

1. Breslau NA. Normal and abnormal regulation of 1,25$(\mathrm{OH})_{2}$ D synthesis. Am J Med Sci 1988; 296: 417- 425.

2. Adams JS, Gacad MA. Characterization of 1 alphahydroxylation of vitamin $D_{3}$ sterols by cultured alveolar macrophages from patients with sarcoidosis. J Exp Med 1985; 161: 755-765.

3. Nishimura $M$, Hara A, Nojima $H$, Noda S, Mashimo $M$, Hori Y. Possible role of the hormonal form of vitamin $\mathrm{D}_{3}$ in the granuloma-associated angiotensin-converting enzyme activity. Sarcoidosis 1987; 8: 101-104.

4. Marusic A, Kos K, Stavljenic A, Vukicevic S. Role of 1,25-dihydroxyvitamin $\mathrm{D}_{3}$ in the generation of the acutephase response in rats with talc-induced granulomatosis. Experientia 1991; 49: 693-698.

5. Basile JN, Liel Y, Shary J, Bell NH. Increased calcium intake does not suppress circulating 1,25-dihydroxyvitamin D in normocalcemic patients with sarcoidosis. J Clin Invest 1993; 91: 1396-1398.

6. Zerwekh JE, Pak CY, Kaplan RA, et al. Pathogenetic role of 1 alpha, 25-dihydroxyvitamin D in sarcoidosis and absorptive hypercalciuria: different response to prednisolone therapy. J Clin Endocrinol Metab 1980; 51: 381-386.

7. Stern PH, De-Olazabal J, Bell NH. Evidence for abnormal regulation of circulating 1 alpha, 25-dihydroxyvitamin D in patients with sarcoidosis and normal calcium metabolism. J Clin Invest 1980; 66: 852-855.

8. Adams JS, Gacad MA, Anders A, Endres DB, Sharma OP. Biochemical indicators of disordered vitamin D and calcium homeostasis in sarcoidosis. Sarcoidosis 1986; 3: $1-6$.

9. Alberts C, van-den-Berg H. Calcium metabolism in sarcoidosis. A follow-up study with respect to parathyroid hormone and vitamin D metabolites. Eur J Respir Dis 1986; 68: 186-194.

10. Rottoli P, Rottoli L, Gommelli S, et al. Abnormalities in calcium metabolism in sarcoidosis. Sarcoidosis 1991; 8: 180-181.

11. Sharma O. Vitamin D, calcium, and sarcoidosis. Chest 1996; 109: 180-181.

12. Harrel GT, Fisher FS. Blood chemical changes in Boeck's sarcoid with particular reference to protein, calcium and phosphate values. J Clin Invest 1939; 18: 687-693.

13. Lieberman J, Nosal A, Schlessner A, et al. Serum angiotensin-converting enzyme for diagnosis and therapeutic evaluation of sarcoidosis. Am Rev Respir Dis 1979; 120: 329-335.

14. Rigat B, Hubert C, Corvol P, et al. An insertion/deletion polymorphism in the angiotensin 1-converting enzyme gene accounting for half the variance of serum enzyme levels. J Clin Invest 1990; 86: 1343-1346.

15. Izumi T. Population difference in clinical features and prognosis of sarcoidosis throughout the world. Sarcoidosis 1992; 9: 105-118.

16. Zweig MH, Campbell G. Receiver-operating characteristic (ROC) plots: a fundamental evaluation tool in clinical medicine [published erratum appears in Clin Chem 1993; 39: 1589]. Clin Chem 1993; 39: 561-577.

17. Coe FL, Bushinsky DA. Pathophysiology of hypercalciu- ria. Am J Physiol 1984; 247: F1-F13.

18. Costabel U. Consensus conference: activity of sarcoidosis. Eur Respir J 1994; 7: 624-627.

19. Cohen MS, Mesler DE, Snipes RG, Gray TK. 1,25-Dihydroxyvitamin $\mathrm{D}_{3}$ activates secretion of hydrogen peroxide by human monocytes. J Immunol 1986; 136: 1049-1053.

20. Fels AO, Nathan CF, Cohn ZA. Hydrogen peroxide release by alveolar macrophages from sarcoid patients and by alveolar macrophages from normals after exposure to recombinant interferons alpha $\mathrm{A}$, beta, and gamma and 1, 25-dihydroxyvitamin $\mathrm{D}_{3}$. J Clin Invest 1987; 80: 381-386.

21. Abu-Amer Y, Bar-Shavit Z. Impaired bone marrowderived macrophage differentiation in vitamin $\mathrm{D}$ deficiency. Cell Immunol 1987; 151: 356-368.

22. Prehn JL, Fagan DL, Jordan SC, Adams JS. Potentiation of lipopolysaccharide-induced tumor necrosis factor-alpha expression by 1,25 -dihydroxyvitamin $\mathrm{D}_{3}$. Blood 1992; 80: 2811-2816.

23. Abu-Amer Y, Bar-Shavit Z. Regulation of TNF-alpha release from bone marrow-derived macrophages by vitamin D. J Cell Biochem 1994; 55: 435-444.

24. Reichel H, Koeffler HP, Tobler A, Norman AW. 1 alpha, 25-Dihydroxyvitamin $\mathrm{D}_{3}$ inhibits gamma-interferon synthesis by normal human peripheral blood lymphocytes. Proc Natl Acad Sci USA 1988; 84: 3385-3389.

25. Fraher LJ, Caveney AN, McFadden RG. Calcitriol and its synthetic analogue MC 903 inhibit the interleukin2 -induced migration of human lymphocytes. Am J Respir Cell Mol Biol 1991; 12: 669-675.

26. Vanham G, Van-Baelen H, Tan BK, Bouillon R. The effect of vitamin $\mathrm{D}$ analogs and of vitamin $\mathrm{D}$ binding protein on lymphocyte proliferation. J Steroid Biochem 1991; 29: 381-386.

27. Yu XP, Hustmyer FG, Garvey WT, Manolagas SC. Demonstration of a 1,25-dihydroxyvitamin $\mathrm{D}_{3}$-responsive protein in human lymphocytes: immunologic crossreactivity and inverse regulation with the vitamin D receptor. Proc Natl Acad Sci USA 1991; 88: 8347-8351.

28. McFadden RG, Vickers KE, Fraher LJ. Lymphocyte chemokinetic factors derived from human tonsils: modulation by 1,25-dihydroxyvitamin $\mathrm{D}_{3}$ (calcitriol). $A m J$ Respir Cell Mol Biol 1992; 4: 42-49.

29. Biyoudi-Vouenze R, Cadranel J, Valeyre D, Milleron B, Hance AJ, Soler P. Expression of $1,25(\mathrm{OH})_{2} \mathrm{D}_{3}$ receptors on alveolar lymphocytes from patients with pulmonary granulomatous diseases. Am Rev Respir Dis 1991; 143: 1376-1380.

30. Ben-Dror I, Koren R, Liberman UA, Erman A, Ziegler R, Ravid A. Foreign body granulomatous inflammation increases the sensitivity of splenocytes to immunomodulation by 1,25 -dihydroxyvitamin $\mathrm{D}_{3}$. Int $J$ Immunopharmacol 1993; 15: 275-280.

31. Yamamoto N, Kumashiro R. Conversion of vitamin $\mathrm{D}_{3}$ binding protein (group-specific component) to a macrophage activating factor by the stepwise action of betagalactosidase of B cells and sialidase of T cells. J Immunol 1993; 151: 2794-2802.

32. Hunninghake GW, Gadek JE, Young RG, Kawanami O, Ferrans VJ, Crystal RG. Maintenance of granuloma formation in pulmonary sarcoidosis by T lymphocytes within the lung. New Engl J Med 1980; 302: 594-598.

33. Nagai S, Takeuchi M, Izumi T. The role of BALF macrophages on pathogenesis of the epithelioid cell granuloma formation in pulmonary sarcoidosis. In: Yoshida T, Torisu M, eds. Basic Mechanisms of Granulomatous Inflammation. Amsterdam, Elsevier Science Publishers, 1989; pp. 265-277.

34. Nagai S, Izumi T. Bronchoalveolar lavage fluid cell findings in patients with extrathoracic sarcoidosis. Semin Respir Med 1992; 13: 393-398.

35. Nagai S, Izumi T. Pulmonary sarcoidosis: population differences and pathophysiology. South Med J 1995; 88: 1001-1010. 